\title{
Penambahan Jus Daun Sirih (Piper bettle linn ) Terhadap Bobot Badan Ayam Broiler
}

\author{
Oleh : \\ Anang Widigdyo, S.Pt \\ Fakultas Peternakan Universitas Islam Balitar \\ Jl. Mojopahit No. 4 Blitar, Jawa Timur
}

\begin{abstract}
Rapid growth rate in broilers is always followed by a rapid fatty liver, in which fat storage tends to increase with increasing body weight. The rapid growth in broilers that are often followed by a fatty is higher, it becomes a problem for consumers who want a chicken with a low fatty.

The purpose of this study was to determine the effect of adding the juice of betel leaves to body weight of broiler chickens. This research was conducted in 9 March to 6 April 2014 for 28 days at Hamlet Village Kedungrejo Salamrejo Binangun District of Blitar. This research used an experimental method that uses a completely randomized design (CRD) using 4 treatments with 5 replicates, each replicate consisting 5 Broiler.

The Results showed the treatment had no significant effect $(\mathrm{P}=0.05)$ on body weight. Based on statistical calculations did not show any differences. The absence of significant differences is due to the weight of the chicken that uniform between treatments and content of feed used primarily energy and protein in the diet is almost the same.

Keyword : Betlle Leaf Juice, Broiler Again, FCR
\end{abstract}

\section{Pendahuluan}

Kebutuhan protein hewani saat ini sangat meningkat seiring bertambahnya jumlah penduduk dan meningkatnya kesadaran masarakat akan pentingnya gizi. Komoditas peternakan terbesar di Indonesia saat ini berasal dari sektor perunggasan meliputi ayam ras petelur dan ayam pedaging dan populasi ayam saat ini sudah menyebar diseluruh Indonesia. Hal tersebut dapat berdampak positif bagi masyarakat Indonesia, karena dapat menciptakan sektor lapangan kerja di bidang peternakan terutama dari sektor perunggasan.

Keberhasilan suatu usaha peternakan ayam dipengaruhi oleh tiga faktor utama yaitu, pakan, bibit, dan menejemen. Ketiga faktor ini merupakan satu kesatuan yang tidak dapat dipisahkan dan saling menunjang satu sama lain (Wiharto, 1986).

Laju pertumbuhan yang cepat pada ayam pedaging selalu diikuti perlemakan yang cepat, dimana penimbunan lemak yang cenderung meningkat sejalan dengan meningkatnya bobot badan. Pertumbuhan yang cepat pada ayam pedaging yang sering diikuti pelemakan yang tinggi, keadaan ini menjadi masalah bagi konsumen yang menginginkan daging ayam dengan perlemakan yang rendah.

Usaha peternakan ayam broiler yang menguntungkan dan banyak diminati konsumen jika daging ayam yang dihasilkan memiliki lemak yang rendah dan bobot badan yang besar. Salah satu upaya untuk meningkatkan pertambahan bobot badan ayam broiler adalah dengan menambahkan jus daun sirih (Piper bettle linn). Diduga kandungan senyawa anti oksidan daun sirih dapat menurunkan kadar lemak, kolesterol dan bakteri E. coli dalam usus serta dapat meningkatkan pertambahan bobot badan.

Rasyaf (2004), menyatakan bahwa ayam dan jenis unggas lainnya membutuhkan sejumlah nutrisi yang lengkap untuk menunjang hidupnya, untuk pertumbuhan dan untuk 
berproduksi. Unggas membutuhkan lebih dari 40 material kimiawi yang diklasifikasikan ke dalam enam kelas yakni karbohidrat, lemak, protein, vitamin, mineral dan air. Semuanya harus ada dalam ransum yang dimakan kemudian dinyatakan bahwa kandungan nutrisi pada fase starter mengandung protein 19,5 - 21,2\%, energi metabolisme $2851-3180 \mathrm{kkal} / \mathrm{kg}$ ransum sedangkan finisher protein 22,0 - 22,7\% dan energi metabolisme $3290-3399 \mathrm{kkal} / \mathrm{kg}$ ransum.

Daun sirih dapat tumbuh dengan ketinggian mencapai 15 meter. Batang daun sirih berwarna coklat kehijauan yang beruas sebagai tempat keluarnya akar. Helaian daun berbentuk jantung tumbuh berselang seling, bertangkai, dan dilengkapi dengan daun pelindung (Wikipedia,2014). Darwis,1991 (dalam Hanafiah, 2009) menyatakan komposisi daun sirih dalam $100 \mathrm{ml}$ infus encer mengandung leusin $18,3 \mathrm{mg}$, fenialanin $14,2 \mathrm{mg}$, serine $22,1 \mathrm{mg}$, asam aspartat $23,0 \mathrm{mg}$, asam glutamate $29,7 \mathrm{mg}$, metionin $13,5 \mathrm{mg}$, valin $3,8 \mathrm{mg}$, tirosin 1,2 $\mathrm{mg}$, asam amino dan butirat $20,2 \mathrm{mg}$.

Minyak atsiri dalam daun sirih berupa minyak terbang (bettle phenol), siskuiterpen, pati, diastase, gula dan zat lemak dan kavikol yang memiliki daya mematikan kuman, anti oksidasi dan fungisida (Wikipedia,2014). Daun sirih memiliki daya anti bakteri terhadap beberapa bakteri pantogen. Minyak esensial daun sirih mengandung komponen fenolik seperti kavikol dan eugenol (Mahardika, dkk, 2012 ) .Rosiana, et al, 1991 dalam Hanafiah, (2009) menyatakan sirih secara umum mengandung minyak atsiri 1-4,2\% hidroksi kavikol, kavikol, kabivetol, esragol, eugenol, metal eugenol, karvakrol, terpena, seskuiterpena, fenil propane, tannin, enzim diastase $0,8-1,8 \%$ enzim katalase, gula, pati dan vitamin A, B dan C. Hidaningtyas,(2008) menyatakan bahwa pemakaian daun sirih untuk obat disebabkan adanya minyak atsiri yang dikandungnya. Bahan yang terkandung di dalam sirih yang berperan sebagai antiseptik adalah katekin dan tannin yang merupakan senyawa polifenol.

\section{Materi Dan Metode Penelitian}

Penelitian ini dilaksanakan pada bulan Maret - April 2014 selama 28 hari di Dusun Kedungrejo Desa Salamrejo Kecamatan Binangun Kabupaten Blitar.Penelitian ini menggunakan DOC boiler starin Hybro dari PT. Manggis . Ayam broiler yang digunakan sebanyak 100 ekor dengan pakan yang digunakan merupakan pakan basal buatan pabrik.

Kandang yang digunakan selama penelitian adalah kandang box ukuran $(1 \mathrm{x} 2) \mathrm{m}$ untuk pemeliharaan ayam broiler umur 1 - 14 hari, selanjutnya menggunakan kandang liter dengan ukuran $(2 \times 5,6) \mathrm{m}$ di beri sekat dengan ukuran $(0,75 \times 0,75) \mathrm{m}$ sebanyak 20 buah, yang berisi 5 ekor ayam di setiap sekat untuk pemeliharaan ayam broiler umur 14 sampai panen. Masing masing kandang dilengkapi tempat pakan dan tempat minum yang terbuat dari bahan pipa paralon.

Pada penelitian ini menggunakan pakan jadi 511 yang di produksi oleh PT. Charoend Phokpand untuk pemeliharaan ayam broiler umur 1-14 hari dan menggunakan pakan BR 1 EX yang diproduksi oleh PT. Chargill Indonesia untuk ayam broiler umur 14 sampai panen.

\section{Pembuatan Daun Jus Sirih Segar}

Sebanyak 100 gram daun sirih segar di cuci bersih ditambahkan $400 \mathrm{ml}$ aquades kemudian di blender selam 10 menit, selanjutnya di campurkan pada pakan sesuai dengan level perlakuan. Penambahan jus daun sirih pada air minum dilakukan dengan cara dicampurkan pada air minum. Ukuran pemberian jus daun sirih di sesuaikan dengan level perlakuan dan di campur dalam air minum dan dilakukan pada jam 07.00.

Perlakuan penambahan jus daun sirih pada air minum dilaksanakan pada ayam broiler berumur 14 hari. Sebelum dilakukan penambahan jus daun sirih, ayam di timbang untuk di ketahui pertambahan bobot badan . 


\section{Metode Penelitian}

Penelitian ini menggunakan metode experimental yang menggunakan Rancangan Acak Lengkap ( RAL) menggunakan 4 perlakuan dengan 5 kali ulangan yang masing-masing ulangan terdiri 5 ekor ayam. Perlakuan yang digunakan dalam penelitian adalah sebagai berikut

P0 : $1000 \mathrm{ml}$ air minum tanpa penambahan

P1 : $1000 \mathrm{ml}$ air minum $+25 \mathrm{ml}$ jus daun sirih

P2 : $1000 \mathrm{ml}$ air minum $+32,5 \mathrm{ml}$ jus daun sirih

P3 : $1000 \mathrm{ml}$ air minum $+50 \mathrm{ml}$ jus daun sirih

Data yang diperoleh di analisis dengan sidik ragam Analysis of Variance ( Anova ) apabila terjadi pengaruh yang nyata atau sangat nyata maka dilanjutkan dengan uji Ducan untuk mengetahui perbedaan antar perlakuan, dengan model matematika seperti di bawah :

Keterangan :

$$
\mathrm{Yij} \quad=\mu+\alpha \mathrm{i}+\varepsilon \mathrm{ij}
$$

Yij $=$ Respon percobaan dari perlakuan ke- $\mathrm{i}$ ulangan $\mathrm{ke}-\mathrm{j}$

$\mu \quad=$ Rataan umum

$\alpha \mathrm{i}=$ Pengaruh perlakuan ke- $\mathrm{i}$

eij = Eror perlakuan ke- $\mathrm{i}$ ulangan ke- $\mathrm{j}$

i $\quad=1,2,3,4$

\section{Hasil Pengamatan Dan Pembahasan}

Secara lengkap data hasil pengamatan bobot selama penelitian di tunjukkan pada tabel 1 di bawah ini.

Tabel 1. Data Pengamatan Bobot Badan Ayam Broiler

\begin{tabular}{|c|c|c|c|c|c|}
\hline $\begin{array}{c}\text { Perlakuan } \\
\text { (kode) }\end{array}$ & \multicolumn{5}{|c|}{ Ulangan } \\
\cline { 2 - 6 } & 1 & 2 & 3 & 4 & 5 \\
\hline P0 & 1580,0 & 1583,0 & 1569,0 & 1570,0 & 1567,0 \\
\hline P1 & 1550,0 & 1560,0 & 1570,0 & 1490,0 & 1525,0 \\
\hline P2 & 1545,0 & 1560,0 & 1580,0 & 1570,0 & 1568,0 \\
\hline P3 & 1560,0 & 1495,0 & 1570,0 & 1540,0 & 1489,0 \\
\hline
\end{tabular}

Sumber : Data Primer Yang Di Olah (2014).

Hasil rata-rata pengukuran penambahan bobot badan ayam broiler yang di beri perlakuan jus daun sirih secara lengkap disajikan pada tabel di bawah ini.

Tabel 2. Rata -Rata Peanambahan Bobot Badan Ayam Broiler (G/Ekor/Minggu) Selama 28 Hari.

\begin{tabular}{|c|c|}
\hline Perlakuan & Rata-rata PBB \\
\hline P0 & $1573,80 \pm 7,19$ \\
\hline P1 & $1539,00 \pm 32,09$ \\
\hline P2 & $1564,60 \pm 13,06$ \\
\hline P3 & $1530,80 \pm 37,09$ \\
\hline
\end{tabular}

Sumber : Data Primer Yang Di Olah (2014).

Hasil pengamatan pada tabel 3 menunjukkan bahwa rata-rata bobot badan ayam broiler terendah di capai pada perlakuan P3 yaitu sebesar 1530 gram dengan penambahan jus daun sirih volume $50 \mathrm{ml}$ pada air minum, sedangkan rata-rata bobot badan ayam broiler tertinggi di 
capai pada perlakuan P0 yaitu sebesar 15731 dengan tanpa penambahan jus daun sirih pada air minum. Secara berturut-turut rataan bobot badan ayam broiler dari yang tertinggi ke yang terendah di mulai P0, P1, P2 dan P3.

Data analisis sidik ragam pengaruh penambahan jus daun sirih terhadap bobot badan ayam broiler secara lengkap disajikan pada table 6 di bawah ini.

Tabel 3. Analisis Sidik Ragam Bobot Ayam

\begin{tabular}{|c|c|c|c|c|c|c|c|}
\hline \multirow{3}{*}{$\begin{array}{c}\text { Sumber } \\
\text { Keragaman }\end{array}$} & \multirow{3}{*}{$\begin{array}{l}\mathrm{db} \\
3 \\
\end{array}$} & \multirow{3}{*}{$\begin{array}{c}\text { JK } \\
6262,15\end{array}$} & \multirow{3}{*}{$\begin{array}{c}\text { KT } \\
2087,38\end{array}$} & \multirow{2}{*}{\multicolumn{2}{|c|}{ F-hitung }} & \multicolumn{2}{|c|}{ F-tabel } \\
\hline & & & & & & \multirow{2}{*}{$\begin{array}{c}\% \\
3,24 \\
\end{array}$} & \multirow{2}{*}{$\begin{array}{l}1 \% \\
5,29 \\
\end{array}$} \\
\hline & & & & 3,18 & ns & & \\
\hline Galat & 16 & 10512,80 & 657,05 & & & & \\
\hline Total & 19 & 16774,95 & & & $\mathrm{KK}=$ & $1,65 \%$ & \\
\hline
\end{tabular}

Sumber : Data Primer Yang Di Olah (2014).

Hasil analisis sidik ragam menunjukkan bahwa level penambahan jus daun sirih pada air minum tidak berpengaruh sangat nyata $(\mathrm{P}>0,05)$ terhadap bobot badan ayam broiler. Analisis ragam menunjukkan perlakuan tidak berpengaruh nyata $(P=0,05)$ terhadap bobot badan. Berdasarkan perhitungan secara stastistik tidak memperlihatkan adanya perbedaan. Tidak adanya perbedaan yang nyata ini disebabkan oleh bobot ayam yang seragam antar perlakuan dan kandungan pakan yang digunakan terutama energi dan protein dalam pakan hampir sama.

Pada penelitian ini, walaupun terdapat perbedaan secara numerik pada setiap kelompok perlakuan terhadap performa broiler tetapi secara statistik tidak ada perbedaan yang nyata diantara kelompok tersebut.

\section{Nilai FCR Ayam Broiler}

Secara lengkap data pengamatan FCR ayam broiler pada umur 28 hari di sajikan pada tabel di bawah ini.

Tabel 4. Data Pengamatan Nilai FCR Ayam Broiler Umur 28 Hari

\begin{tabular}{|c|c|c|c|c|c|}
\hline \multirow{2}{*}{$\begin{array}{c}\text { Perlakuan } \\
\text { (kode) }\end{array}$} & \multicolumn{5}{|c|}{ Ulangan } \\
\cline { 2 - 6 } & 1 & 2 & 3 & 4 & 5 \\
\hline A & 1,489 & 1,486 & 1,499 & 1,498 & 1,501 \\
\hline B & 1,517 & 1,508 & 1,498 & 1,579 & 1,542 \\
\hline C & 1,522 & 1,508 & 1,489 & 1,498 & 1,500 \\
\hline D & 1,508 & 1,573 & 1,498 & 1,527 & 1,580 \\
\hline
\end{tabular}

Sumber : Data primer yang diolah (2014).

Hasil rata-rata pengukuran nilai FCR ayam broiler yang di beri perlakuan jus daun sirih secara lengkap disajikan pada tabel di bawah ini:

Tabel 5. Rataan Nilai FCR Ayam Broiler Umur 28

\begin{tabular}{|c|c|}
\hline Perlakuan & Rata-rata FCR \\
\hline P0 & $1,494 \pm 0,007$ \\
\hline P1 & $1,529 \pm 0,032$ \\
\hline P2 & $1,503 \pm 0,013$ \\
\hline P3 & $1,537 \pm 0,037$ \\
\hline
\end{tabular}

Sumber : Data primer yang diolah (2014).

Hasil pengamatan pada tabel 5 menunjukkan bahwa rata-rata FCR ayam broiler terendah di capai pada perlakuan P0 yaitu sebesar 1,494 dengan tanpa perlakuan penambahan jus daun sirih pada air minum, sedangkan rata-rata FCR ayam broiler tertinggi di capai pada 
perlakuan P3 yaitu sebesar 1,537 dengan penambahan jus daun sirih volume $50 \mathrm{ml}$ pada air minum. Secara berturut-turut rataan bobot badan ayam broiler dari yang tertinggi ke yang terendah di mulai P3, P1, P2 dan P0.

Data analisis sidik ragam pengaruh penambahan jus daun sirih terhadap FCR ayam broiler secara lengkap disajikan pada tabel 9 di bawah ini.

Tabel 61. Hasil Sidi Ragam Nilai FCR Ayam Broiler Setelah Diberi Penambahan Jus Daun Sirih

\begin{tabular}{|lrrrrr|}
\hline Sumber Keragaman & Jumlah Total & \multicolumn{1}{l}{ Db } & Rataan & F & Sig. \\
Perlakuan & 18.000 & 12 & 1.500 & 1.500 & .303 \\
Galat & 7.000 & 7 & 1.000 & & \\
Total & 25.000 & 19 & & & \\
\hline
\end{tabular}

Sumber : Data primer yang di olah (2014)

Hasil analisis sidik ragam menunjukkan bahwa level penambahan jus daun sirih pada air minum tidak berpengaruh sangat nyata $(\mathrm{P}>0,05)$ terhadap nilai FCR ayam broiler. Analisis ragam menunjukkan perlakuan tidak berpengaruh nyata $(\mathrm{P}=0,303)$ terhadap FCR. Berdasarkan perhitungan secara stastistik tidak memperlihatkan adanya perbedaan. Tidak adanya perbedaan yang nyata ini disebabkan oleh bobot ayam yang seragam antar perlakuan dan kandungan pakan yang digunakan terutama energi dan protein dalam pakan hampir sama.

Pada penelitian ini, walaupun terdapat perbedaan secara numerik pada setiap kelompok perlakuan terhadap performa broiler tetapi secara statistik tidak ada perbedaan yang nyata diantara kelompok tersebut.

\section{Kesimpulan Dan Saran}

\section{Kesimpulan}

Berdasarkan hasil penelitian dan pembahasan maka dapat disimpulkan bahwa Penambahan jus daun sirih dalam air minum tiap perlakuan tidak berpengaruh nyata terhadap penambahan bobot badan ayam broiler.

\section{Saran}

Perlunya penelitian lebih lanjut mengenai penambahan daun sirih terhadap bobot badan ayam broiler dengan variasi volume jus daun sirih sehingga diperoleh hasil yang maksimal.

\section{Daftar Pustaka}

Arauna, Y, dkk. 2012. Studi Kadar dan Gambaran Trigliserida Hispatologi Hepar Hewan Model Tikus (Rattus orvegicus) Hiperkolesterolemia yang diterapi Dengan Ekstrak Air Benalu Mangga ( Dendrophthoe petandra). Jurnal Fakultas Kedokteran Hewan Universitas Brawijaya. http://www. pkh.ub.ac.id/wpcontent/uploads/2012/10/0911310028-Yosia-Arauna.pdf. Di Akses tanggal 28 Juni 2014.

BPS. 2014. Peternakan. http://www.bps.go.id/ tab_sub/view.php?tabel $=1 \&$ daftar=1\&id_subyek=24\&notab=12. Di akses tanggal 15 Juli 2014. 
Fadilah, R. 2005. Panduan Mengelola Peternakan Ayam Broiler Komersial. Agromedia Pustaka:Jakarta.

Fadilah,R.2004. Panduan Beternak Ayam Broiler Komersial.Agromedia Pustaka:Jakarta.

Fitriani,I.2009.Manajemen Perkandangan Ayam Layer Di Rossa Farm Desa Kendalrejo Kecamatan Srengat Kabupaten Blitar. Laporan PKL : UIB Blitar.

Hanafiah, T.H. 2009. Kadar Kolesterol Serum Darah Ayam Petelur Yang Diberi Air Rebusan Daun Sirih. Skripsi. Fakultas Peternakan Institut Pertanian Bogor.

Hidayatiningtyas, P. 2008. Perbandingan Efek Antibakteri Air Seduhan Daun Sirih (Piper bettle linn) Terhadap streptococcus mutans Pada Waktu Kontak dan Konsentrasi yang Berbeda. Fakultas Kedokteran Universitas Diponegoro Semarang.

Murtijo,B.A. 1987. Pedoman Beternak Ayam Broiler. Jogjakarta : Kasinius.

Rasyaf, M.2008. Beternak Ayam Pedaging. Jakarta : Penebar Swadaya.

Risyana,Wemvi.2008.Kinerja Supply Chain Management Komoditi Ayam Nene (Grand Parenstock Broiler) di PT Galur Cobbindo Sukabumi. Skripsi: digilip.ipb.ac.id. 4 Juli 2013. 